\title{
Encountering Maude Abbott
}

\author{
Annmarie Adams ${ }^{1 *}$
}

Published: September 27, 2018

\begin{abstract}
This paper explores the ways in which traditional approaches to biography have inscribed and reinforced gendered hierarchies in medicine. Like many other accomplished women, the life story of Canadian cardiologist Maude Abbott (1869-1940) has been told through narratives of constraint. For example, existing biographies of Abbott have focused on her relationship to famous men, such as her cousin Prime Minister John Abbott, her mentor, distinguished physician William Osler, her benefactor, the philanthropist Lord Strathcona, and her nemesis, the pathologist Horst Oertel. Abbott's biographers have granted her negligible agency in how her life unfolded. A material culture approach to Abbott's life, inspired by feminist art and architectural history, means focusing on alternative sources, in particular buildings, artefacts, and representations, rather than the obstacles Abbott faced and the men who supported or rejected her. This trans-disciplinary method, which both encounters Abbott's lived experiences and counters traditional narratives, allows us to assess her work in new ways. For example, Abbott's research generated global networks and was foundational in the rise of the medical museum, her magnum opus. Such an approach offers new insights into the ways in which the Medical Humanities, and in particular the history of medicine, are entwined with feminist thought and agency.
\end{abstract}

Keywords: medicine, woman, agency, architecture, biography

\section{INTRODUCTION}

Dr Maude Abbott (1869-1940) leans forward and stares confidently at the viewer in an undated portrait painted by her childhood friend, Mary Alexandra Bell Eastlake (Figure 1). ${ }^{1}$ The triangular form of the Canadian physician's head and upper body fill the rectangular painting, with the dull grey of her hair and non-descript clothing almost merging with the plain blue background of the scene. Eastlake provides no clues that the sitter is a world-renowned cardiologist and medical museum curator. While many paintings of medical doctors include identifiable architectural settings (surgery, clinic), clothing (lab coat), and medical technologies (stethoscope) to suggest a sitter's medical identity, Eastlake's painting includes no such professional references. ${ }^{2}$ Nor is there any nod to the influential medical museum Abbott created at McGill University in Montreal. Eastlake focuses instead on the famous doctor's overall 'intelligence and hard work,' confidence, and all-knowing composure (Wright et al., 2017: 282). Abbott's plain dress and grey hair, the dark circles under her eyes, abstract backdrop, delicate necklace and posture of grandeur emphasise, instead, a life of generic hard work, not necessarily connected to medicine. This unfixed identity may be one reason that the sitter depicted in the painting was only recently identified as Abbott, erroneously referred to until its rediscovery in 2006 simply as a painting of An Old Woman (Wright et al., 2017: 281).

Today, Abbott's anonymity in the Eastlake portrait and beyond is difficult to explain. Maude Elizabeth Seymour Abbott is both a Canadian hero and a medical superstar. She is the subject of several book-length biographies, a historical novel, dozens of articles, and in 2000, her likeness even appeared on a Canadian postage stamp. Among Canada's first female medical graduates, she was best known during her lifetime as the curator of McGill University's medical museum and posthumously as a researcher of congenital heart malformations. She excelled in both roles. She didn't just run the museum at McGill, for example, she was the 'alpha and omega of medical

${ }^{1}$ Abbott herself refers to Eastlake as 'my childhood 'best friend" in her 36-page, typed Autobiographical Sketch (31 March 1928), Osler Library of the History of Medicine, McGill University. The quote also appears in the McGill Medical Journal (Abbott, 1959: 131).

2 On the relationship of portraiture and medicine, see Jordanova's Defining Features: Scientific and Medical Portraits 1660-2000 (2000: 66-71). 


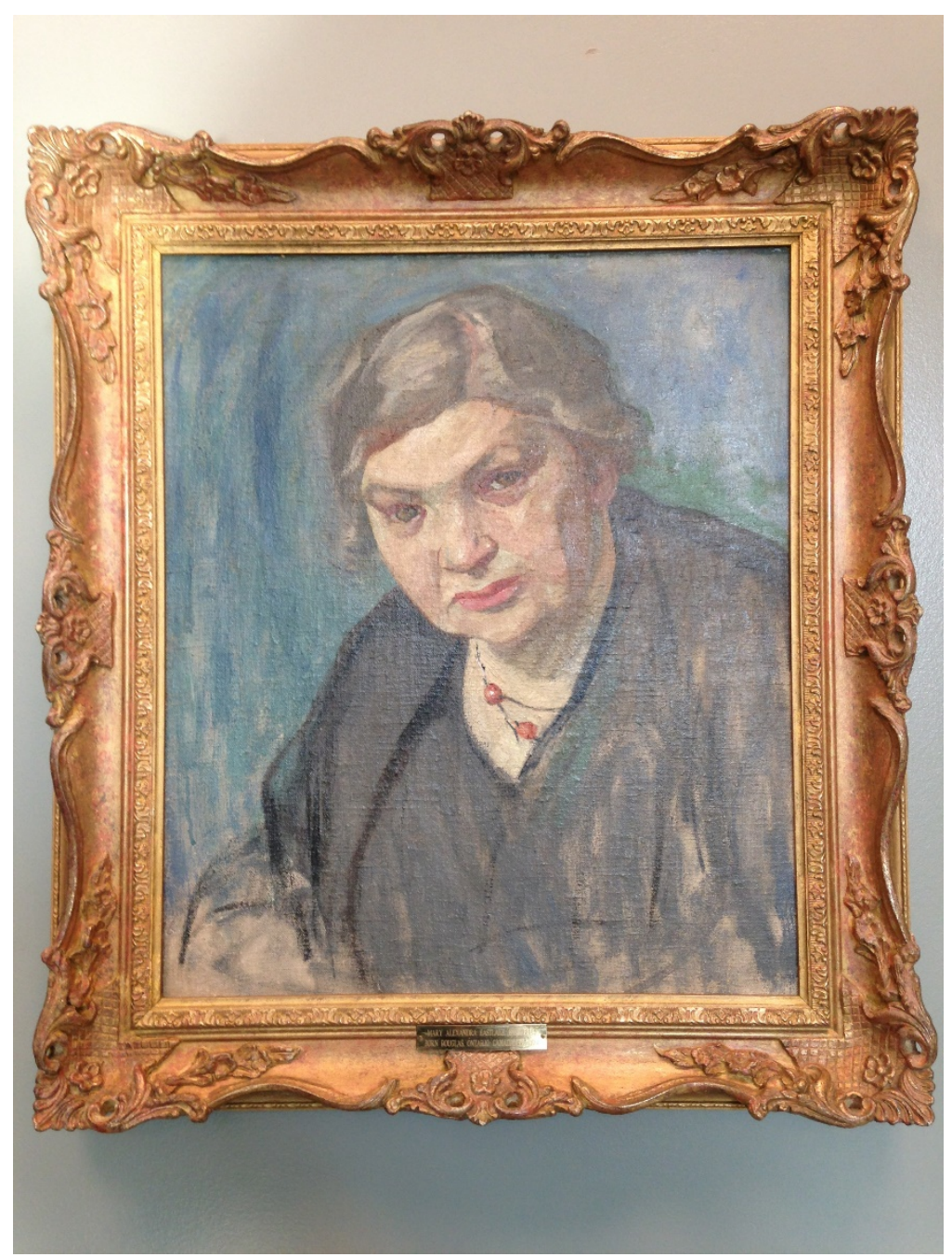

Figure 1. Mary Alexandra Bell Eastlake, Portrait of Maude Abbott, no date, oil on canvas, 20x17 inches. (Reproduced by permission of the Osler Library of the History of Medicine, McGill University)

museums' (McLeary, 2001: 213), serving as the go-to expert for medical museums around the world at the height of their significance in medical education and research. ${ }^{3}$ Similarly, Abbott was much more than an expert on congenital heart malformations, she was 'world famous' as the field's top researcher (Gillett, 1990: 179). When William Osler, 'the best known and best loved physician in the English-speaking world' (Roland, 2003), needed someone to write the "Congenital Cardiac Disease" section of his A System of Medicine, he turned to Abbott (Osler and McCrae, 1908: 323-425). In a letter to Abbott on 23 January 1908, Osler articulated what he saw as Abbott's supreme authority, referring to her contribution to his book: "[The article] is by far + away the very best thing ever written in the subject in English - possibly in any language." 4

Given Abbott's extraordinary medical accomplishments—she is sometimes listed with other Canadian medical giants such as Frederick Banting (1891-1941), Norman Bethune (1890-1939), and Wilder Penfield (1891-1976)_ her life story may seem like an unexpected research subject for an architectural historian of medicine. What draws me to her, however, is the opportunity her rich life offers to model a feminist biography through (1) a long overdue historiographical review of literature assessing her life and work, and (2) exploring material and spatial evidence from the perspective of a woman doctor. Re-telling women's lives through spaces, that is, may be a way to broaden and enrich the histories of art and architecture as well as feminist biography.

The existing biographies of Abbott are textbook examples for feminist critiques of the genre. ${ }^{5}$ Nearly all of them try to fit Abbott's non-conventional life and career into a traditional, biographical arc inspired by men's life

\footnotetext{
${ }^{3}$ At the conference Artistic Practice \& the Medical Museum, held at the Hunterian Museum of the Royal College of Surgeons, London, 6 June 2014, then-director Sam Alberti referred to Abbott as 'the mother superior of medical museums'.

${ }_{4}^{4}$ Osler to Abbott, 23 January 1908, Osler Library of the History of Medicine, McGill University. The letter is also reprinted in Abbott (1959: 146).

5 The biographical articles and books considered here include Abbott (1997); Brookes (2011); Frost (1978); Gillett (1989; 1990); MacDermot (1941); Rothman (2009); Waugh (1992); as well as Abbott's own autobiographical notes from 1928 (note 1).
} 
stories. Biographers focus on her struggle, on what she couldn't do, rather than how she managed her accomplishments. Feminist historian Barbara Caine writes, rather, that:

What is now of interest, even when one is dealing with women who were very prominent as writers, artists, educators or social or political activists, is not just what they did, but how they managed to do it within the familial and social constraints to which, as women, they were subject (1994: 251).

My own starting point for this ambitious, two-part undertaking has been Carolyn Heilbrun's assertion in Writing a Woman's Life that traditional biography is an inappropriate framework for most women's lives: "reading women's lives needs to be considered in the absence of 'a structure of critical' or biographical commonplaces. It all needs to be invented, or discovered, or resaid" (1988: 18-19). She points out that certain motifs common to men's biography were denied to women, especially the claim of achievement, the admission of ambition, the recognition that accomplishment was neither luck nor the result of the efforts or generosity of others (1988: 24). Similarly, women as biographers and subjects are challenged 'in conveying their experience of the world in a narrative format that assumes a male life as its norm,' asserted architectural historian Abigail Van Slyck in 1992, pointing to Heilbrun's theory as a call to action for a new type of feminist architectural biography (1992: 19).

A second thought-provoking text has been architectural historian Dana Arnold's proposition that women's biography and space are in dynamic interplay. In 2007, Arnold called for an interrogation of the spatial boundaries that have worked towards women's exclusion in the accounts of our experiences. In her opening essay to the coedited collection, Biographies and Space, Arnold notes the power of the biographical traces we all leave behindbelongings, spaces, texts—-for telling our life stories. Women have traditionally left far fewer biographical traces in the world and are thus under-represented in archives, museums, and libraries. Looking at architecture and art thus adds powerful and under-used primary sources to the short list of how researchers can get at women's life stories. Literary critics have noted how feminist biographers often use alternative sources such as photography and material culture to compensate for the dearth of traditional textual sources as bearers of women's history (Alpern et al., 1992; Stanley 1990), and make creative use of fragments in constructing life stories (Booth and Burton, 2009a). Since spatial traces often come from disparate places, they are by nature fragmentary. Spatial fragments are particularly important because they are ubiquitous and are located outside these mainstream, institutional collections. As such they offer additional viewpoints, which may be illegible or contrary to the data from written or curated sources. Arnold compellingly suggests that such traces, evolving in time and intersecting with one another, also help us to understand architectural meaning:

[I was prompted to] think about architecture, or rather the space it encloses, and the meanings and identities that can be conferred on objects within that space. The space and the objects do not change but our understanding of them does, and this can be influenced by social and cultural circumstances (2008: 7).

As a key figure in early twentieth-century medicine, Abbott left many material traces in built and archival environments. Unsurprisingly, these have attracted next to no scholarly attention. ${ }^{6}$ Instead, her biographers have relied solely on textual sources, especially on her own autobiographical sketch of $1928^{7}$ and Hugh MacDermot's 'full-scale' (Gillett, 1990: 179) biography that was published in 1941, just after her death. This heavy reliance on two works has meant that the same narrative arc has been repeated in each subsequent biographical account of Abbott's career. None of Abbott's biographers have paid attention to space or images. If images are engaged, for example, they are more often used as illustration than as evidence. Arnold asserts the potential importance of space to biography: "Architecture is not just a platform for viewing the subject, it also produces the subject," she says (2008: 14). Similarly, Susan Mann Trofimenkoff notes how feminist biography lays bare gender as a historical construct and challenges stereotypes just as the 'female subject of such a biography likely challenged stereotypes in her own life' (1985: 4). I contend that art and architecture are among the most significant of those unexamined traces and can inspire new ways of understanding Maude Abbott and other unconventional, active subjects. ${ }^{8}$

\footnotetext{
${ }^{6}$ Abbott left a large archival legacy that includes her journals, correspondence, and publications. The collections of specimens from the original medical museum she curated are also extant and have recently been reconstituted as the Maude Abbott Medical Museum (McGill University, 2018).

${ }^{7}$ Gillett reproduces 20 pages from these notes in "The Lonely Heart" (1989: 202-22).

${ }^{8}$ On women in science, see Fara (2015), and other papers in the special issue of Notes and Records, 69(1) on 'Women and Science'.
} 


\section{COUNTERING MAUDE ABBOTT: HISTORIOGRAPHY AND WHAT IT TELLS US}

The existing biographies of Abbott exemplify at least three major problems in traditional biography. Firstly, they imply that Abbott was completely passive in the way her life unfolded. Writers see her life story as wholly shaped by a series of constraints and by decisions made by others, echoing the observation 'that accomplishment was neither luck nor the result of the efforts or generosity of others' (Heilbrun, 1999: 19). Secondly, noting her unmarried status, biographers suggest that Abbott was instead married to her work, also remarking on behaviour that may have pushed gender norms for the early twentieth century. Thirdly, and not unrelated to Abbott's unmarried state, biographers tend to infantilise, sexualise, and objectify Abbott herself.

Two feminist biographers of Abbott, however, have avoided these pitfalls. Feminist historian of education Margaret Gillett was one of the first researchers to illuminate Abbott's work in the context of women's history. Secondly, historian of women Barbara Brookes undertook an insightful study of Abbott's career in parallel to her caring for her older sister, Alice Abbott, who died in 1934 (Brookes, 2011). While Gillett argues that Abbott's 'eccentricities' (1990: 180) were a coping mechanism for survival in a male-dominated field, Brookes' study underlines the challenges faced by Abbott and other women physicians to keep their private and professional lives distinct, a point also nicely illustrated by the aforementioned Eastlake portrait, where her identity as a physician is obscured. It is difficult to imagine, for example, a portrait of Banting, Bethune, or Penfield going unnamed, or ever given a generic title, such a portrait of An Old Man. Needless to say, sexism has thus had a major impact on her legacy, rendering her life and work less visible and/or recognisable than that of her male colleagues.

\section{Narratives of Constraint}

Like many other women in medicine and science, Abbott's story has been told through narratives of constraint, as if all her life choices were determined by a series of doors closed by others. ${ }^{9}$ Even Gillett's account, arguably the most feminist in its approach, presumes this blatant passivity. Every account, for example, includes the story of Abbott's rejection from McGill University on account of her gender, and her subsequent career as a museum curator as a result of her exclusion from hospital work. "Maude Abbott was also forced to study elsewhere," Gillett says about Abbott's attendance at nearby Bishop's University. Biographer Douglas Waugh declares Abbott's passivity unequivocally: "Maude did not choose the medical museum for her life's work" (1992: 53). Almost all the biographical accounts include the university and the hospital as a series of 'closed doors' to Abbott. In addition to the two cited above-her decision of where to study (or non-decision) and the jump to museum work-we might also include the fact that her father, accused murderer Jeremie Babin, abandoned the family in 1868 (thus leading to the name change, to Abbott), and that her apparent conflict with pathologist Horst Oertel essentially ended her brilliant career as a museum curator. In such accounts, then, these pivotal moments in Abbott's life are determined by the actions of men.

A list of independent actions taken by Abbott, 'doors that opened,' would look like this. McGill University's first medical dean, Charles F. Martin, invited her to write a paper on functional heart murmurs that was eventually published in the Montreal Medical Journal, 'one of her very few bits of purely clinical work,' says MacDermot of this paper (1941: 62-3). Similarly, pathologist George Adami asked her to do a paper on pigmentation-cirrhosis, 'the first unmistakable evidence of her powers in pathological research,' comments MacDermot (1941: 63). These invitations by male colleagues seem minor relative to the deterministic impact biographers ascribe to Abbott's introduction to William Osler in December 1898 at Johns Hopkins University, which supposedly led to his invitation to write for his book and to her subsequent career as a medical curator.

Although many of Abbott's major choices, then, appear to have followed on the heels of invitations offered by men, her life story offers plenty of instances of independent action. Abbott willingly took up challenges with alacrity and made projects her own. The medical museum is an excellent illustration of this. Abbott took considerable care in curating the specimens on display to maximise their teaching potential. She took her role as an educator seriously and shaped the space as an effective teaching tool. She then used what she had learned to advise colleagues around the world in creating their own museums.

An even earlier independent action is her decision to pursue postgraduate study in Europe for three years. Traveling with her sister, Abbott attended the operations of Victor Horsley in London, and subsequently surgeon Vincenz Czerny in Heidelberg. In Bern she observed Theodor Kocher operate. The two women settled in Zurich, finding a place in Hugo Ribbert's laboratory. She stayed two years in Vienna, appreciating the courses of Norbert Ortner, one of the few to accept women. She calls out the courses of Ortner, Eugen Kolisko and Heinrich Albrecht as being particularly influential in her own work: 'determined my bent and made possible my later work at McGill'

${ }^{9}$ Frost says, for example, that Abbott was 'knocking on a closed door' in 1890 (1978: 266). 
(1959: 138). ${ }^{10}$ She gleaned expertise in Listerian methods of asepsis in Glasgow and even worked in an asylum in Birmingham. Slides she obtained during her European travels were useful back in Montreal (1959: 139). She thus saw her personal decision to travel and study as formational and having significant, positive consequences.

\section{Married to Her Work}

Like so many early women in male-dominated fields, Abbott remained unmarried and childless throughout her life. ${ }^{11}$ This made those around her, including and perhaps especially her biographers, unsure of what to call her. During her lifetime, colleagues such as physicians F. J. Shepherd and Thomas Roddick called her 'Miss Abbott' (Waugh, 1992: 60), refusing to address her as Dr. Abbott even though she received her M.D. degree in 1894. Some authors suggest that Abbott's character flaws and/or eccentric personal habits may have shaped her destiny as well as her gender identity. Perhaps employing the term 'mannish' as a code for lesbian, as was common at that time, MacDermot says:

She had a sturdiness of mind which, for the lack of a better term, one might call masculinity, although it never supplanted her essentially feminine qualities. She was never 'mannish.' Sensitive she always was, but her association with men gradually taught her how to take her part in working with them (1941: 81).

Relatedly, biographers explain Abbott's 'spinsterhood' through her 'love' of her work, illustrating how many accomplished women were forced to choose between professional and family responsibilities. Although this loveof-work theme is common in many women's biographies, it may be especially prominent in Abbott's case because of her specialised research on the heart. As is well known, the heart has long been associated with love and romance, perhaps because it was once thought to be the source of emotions. Waugh writes:

There can be no doubting of Maude's affection for McGill, but it was such a one-sided romance that she might have been forgiven if she'd walked away from it (1992: 81).

In her autobiographical sketch, Abbott wrote about this affection as if for another woman: "I was literally in love with McGill or so the girls said, and I have never really fallen out of love with her since" (1959: 129). A family biography, All Heart, written by family member Elizabeth Abbott, echoes this trope of institutional love:

like true ecclesiastical celibates, the 'sublime' state is often not attained without a symbolic crucifixion of the purely natural self. Her sense of the divine found expression in her love not only for individuals but for institutions as well, not the least of which was toward her Alma Mater, McGill (1997: 84).

For some, unmarried Dr. Abbott and her specialisation in cardiology even made her 'The Madonna of the Heart.' As Gillett has noted, the publisher of Abbott's epic The Atlas of Congenital Cardiac Disease, her magnum opus, dedicated the first copy to her with this unexpected inscription (1990: 187).

At the same time, many Abbott biographers infantilise Abbott, a tendency underlined by the overuse of her first name and anecdotes like this regarding her relationship with Martin, whom Abbott described as 'my best friend at the University' (MacDermot, 1941: 105): "Whenever she burst into tears he would console her and she got what she wanted" (Waugh, 1992: 83). Likewise,

Although Maude's hero was Sir William Osler, it was to Dr Martin that she most frequently turned for support and advice on personal matters. In terms of age, they were almost contemporaries but in his frequent letters to her Martin's tone was often that of a doting parent offering praise and encouragement, or chiding her for being too emotional (Waugh, 1992: 113).

"She had an almost child-like innocence when it came to promoting herself," reports Waugh, and "[i]n her frustrations she could burst into tears, which Dr Martin would soothe by solving her problem of the moment" (1992: 91).

Other authors eroticise the relationship between Abbott and Osler, even suggesting that her work was the product of an imagined romance. Waugh's book, Maudie of McGill, is the most alarming example: "The intimacy between Osler and Maude produced a synergism that was the source of much of Maude's professional productivity" (1992: 59). "Like other women who met him," he continues, "Maude fell in love with Osler [...] She remained his acolyte for the rest of her days" (1992: 56). Waugh further claims that:

\footnotetext{
${ }^{10}$ Note Abbott used only surnames in her account. Thank you to Thomas Schlich for assistance with the full references.

${ }^{11}$ Gillett reports that Abbott 'was by no means a man-hater' (1990: 190).
} 
The encouragement she received from Osler was the most powerful stimulus to her in her work, but it was also the inspiration for the almost idolatrous affection that she was to bear for him for the rest of her days (1992: 60).

Waugh's is the most offensive of all the biographical accounts in this regard, even including a chapter title 'The Museum's Lover.' ${ }^{2}$ In The Heart Specialist, a fictionalized account of Abbott's life, novelist Claire Holden Rothman adds a steamy sexual relationship between Abbott, whom she calls Agnes White, and her German-Jewish, workingclass assistant Jakob Hertzlich, whose medical aspirations had been dashed by McGill's quota of Jewish students, a parallel narrative of constraint. In the book's central sex scene, the Abbott-inspired character pulls Jakob towards her after the pair had drunk some champagne. "My eyes stayed closed and there was a sudden surge, like electricity," recounts Rothman. She immediately reverts to Abbott's presumed sexual inexperience and naïveté: “is this what people did? He was like a fish trying to swim inside me. I clamped down and pushed him off' (Rothman, 2009: 208). Such eroticised references can be found outside the Abbott biographies as well. Michael Bliss writes of Abbott in his biography of Osler, "As curator of McGill's medical museum she became almost literally the keeper of [Osler's] body parts” (1999: 347).

Another way to examine Abbott's relationship with Osler is through the letter he wrote in January 1908 that she apparently carried around in her purse. Has the significance of this Osler connection grown out of proportion in the biographical narratives? Perhaps it functions in the same way that Betsy Ross's legendary narrative, told through her unannounced meeting with George Washington, satisfies our appetite for female heroines created by powerful men. This famous legend overshadows the history of the United States flag and a more nuanced life story of Ross, so beautifully told in Marla Miller's recent biography of America's favourite seamstress. ${ }^{13}$ In Abbott's case the stand-in for Washington is Osler. Abbott herself used highly charged language to describe the famous physician's influence on her career. In a much-cited quote from a fateful dinner of Abbott and Osler in Baltimore in December 1898, Abbott engages terminology from reproduction and fertility to illustrate his 'seminal' role: 'And so he gently dropped a seed that dominated all my future work,' she remembered in her autobiography of 1928 (1959: 141). On this same theme, MacDermot's book reproduces the quote and describes Osler's influence as 'fermenting' (1941: 74-5). Even Abbott's own words tend to the erotic, conjuring up images of piercing, veils, stimulation, and passion in a single sentence. She says that Osler's 'keen interest in my work and broad human sympathy pierced the veil of my youthful shyness with a personal stimulus that aroused my intellect to its most passionate endeavour' (1959: 152).

It is important to note that many men also idolized Osler. Bliss describes the widespread adoration Osler enjoyed in a chapter entitled "We All Worship Him":

Everyone loved the Chief. He was so warm, so friendly, so happy and charming, so funny, so interesting and interested (in today's jargon, so upbeat and positive) that he enchanted everyone, from patients to his most senior colleagues [...] nowhere is there dislike of Osler (1999: 226-7).

The fact that Abbott was a woman, however, has led biographers to sexualise the relationship, whereas receiving encouragement from Osler was never seen this way by male physicians. Since the medical climate at McGill was relatively unfriendly, it is not surprising that she basked in his warmth. ${ }^{14}$ Still, noting this difference reveals much about how gender shaped the relationship of pioneering women with the institution, seeing it as something of a stand-in for an absent husband and/or an imagined lover.

\section{ENCOUNTERING MAUDE ABBOTT: MATERIAL EVIDENCE AND WHAT IT TELLS US}

Turning to the material and spatial evidence of Abbott's career, the photographic trace documents Abbott's marginality in a male-dominated sphere, one of Heilbrun's tropes. Her anomalous position in the Montreal medical scene is evident in a photograph (Figure 2) of the Royal Victoria Hospital's (RVH) surgical theatre where Osler performs an autopsy. ${ }^{15}$ Abbott occupies the centre of the top row, watching the proceedings from a shadowy vantage point, perhaps even wearing a dark veil across her face. Although she is at the centre of the image, she is in the furthest row from the central actor, Osler, and is the sole figure in the group whose face is not illuminated.

\footnotetext{
12 This apparently refers to chemist Robert Fulford Ruttan's statement that the museum 'needed a lover' (Abbott, 1959: 142; Frost, 1978: 268).

13 Miller's book is a wonderful model for this study (2010). Other relevant examples include Upton (1996); Byrne (2013); Gordon (2012). On the myth, see Ulrich (2007).

14 I am grateful to Reviewer 1 for this insight.

15 While Osler is the white knight in all accounts, the black knight is Horst Oertel, generally understood to be responsible for Abbott's demotion. The best account of the tensions between Oertel and Abbott is in McLeary (2001: 242-3).
} 


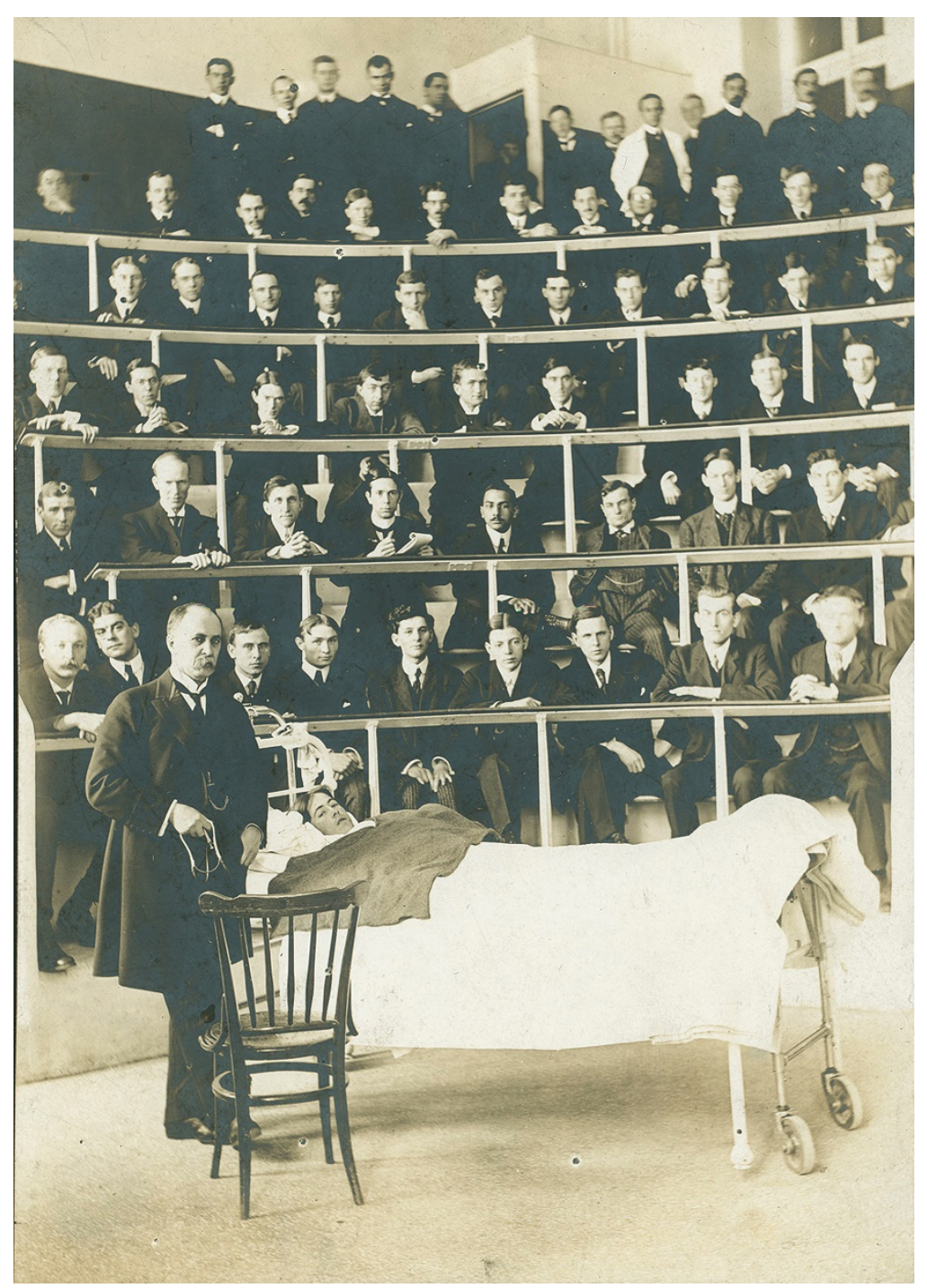

Figure 2. William Osler conducting a clinic at the Royal Victoria Hospital's surgical theatre, Montreal, 1905. (Reproduced by permission of the Osler Library of the History of Medicine, McGill University)

In 1898 Abbott was appointed Assistant Curator of McGill University's Medical Museum (the story goes that this was in lieu of an opportunity to treat live patients). Her mandate as curator was to organise the collection of specimens amassed since 1823 for teaching purposes, and cataloguing approximately 180 (by 1890) specimens collected by Osler himself from 750 autopsies performed at the Montreal General Hospital from 1876 to 1884 (MacDermot, 1941). The first purpose-built site of the university's medical museum (Figures 3-4) was a rather strange, conglomerated building designed by architects Hopkins \& Wily in 1872, with significant additions by Andrew Taylor in 1885, 1895, 1897, and 1901, which eventually dwarfed the original building (Wagg, 2013: 1302). ${ }^{16}$

Nine years later, a fire tore through McGill University's Old Medical Building, destroying the adjacent anatomical museum and 2000 pathological specimens, including the entire bone collection. One thousand specimens were secured, including the famous three-chambered heart known as the Holmes heart. ${ }^{17}$ In the 2009 fictionalised account of Abbott's life, The Heart Specialist, Rothman describes the scene after the fire when Abbott first spotted the burnt-out building from a distance, drawing on a literary analogy: "I felt like Jane Eyre returning to Thornfield Manor after the madwoman had torched it" (2009: 190). ${ }^{18}$ This moment in Charlotte Bronte's 1847 novel parallels the heroine's relative autonomy, allowing her to marry the man she loves rather than one more obviously available. Is Rothman using the Eyre reference to signal the importance of the fire in Abbott's life story?

With the university's Faculty of Medicine left homeless, a new building was constructed, the Strathcona Medical Building, opening its doors as the faculty's second, purpose-built home in 1909. Significantly, the stately new

\footnotetext{
${ }^{16}$ For an expanded analysis of the three museum sites described here, see Adams (2017).

${ }_{17}$ Curator's Report of Donations Received in the Museums of the Medical Faculty of McGill University, 16 April 1907 to 1 July 1910 , Osler Library of the History of Medicine, McGill University.

${ }^{18}$ Note Rothman's fictional account is described as an 'intelligent biography' in Donoghue (2009).
} 


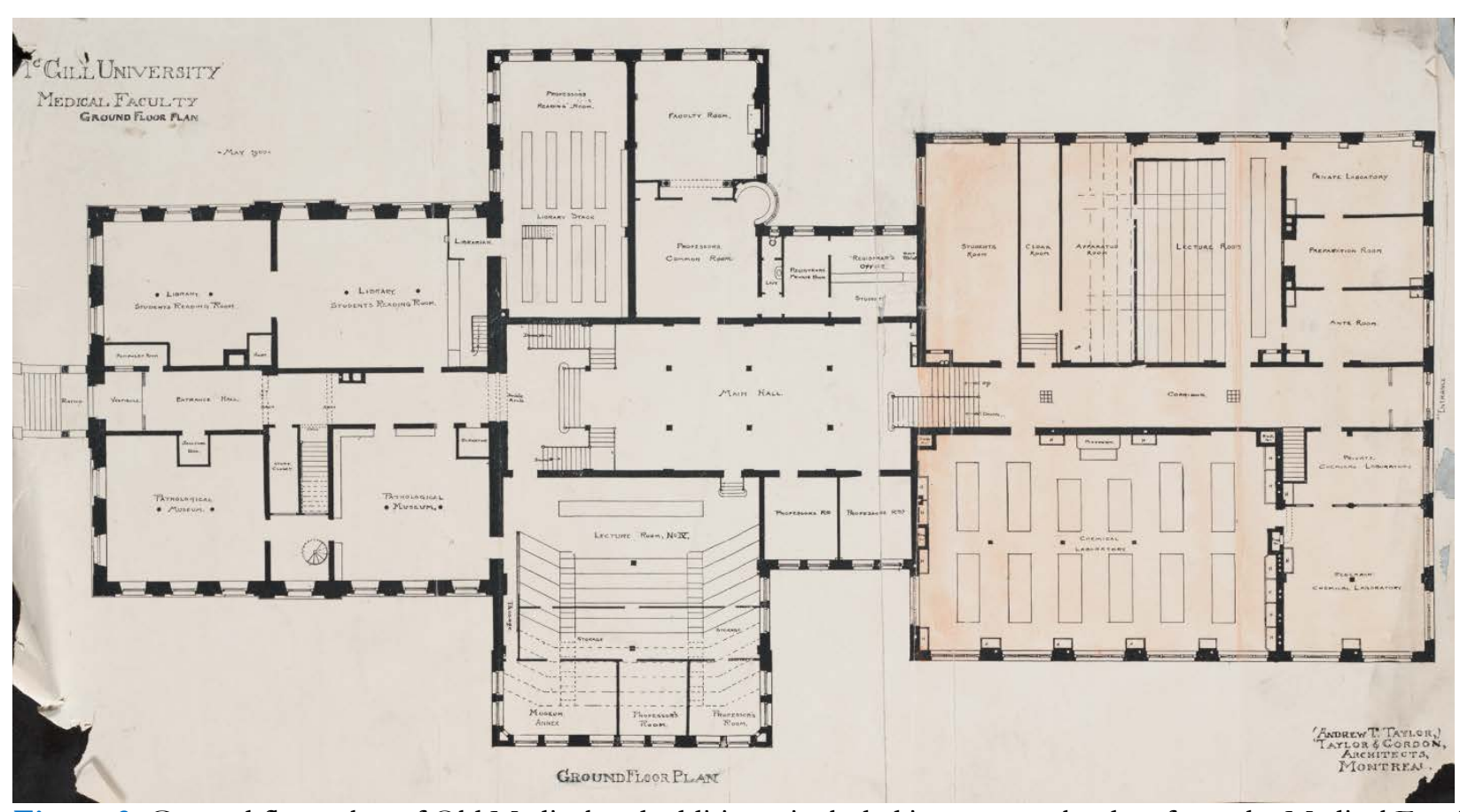

Figure 3. Ground floor plan of Old Medical and additions, included in course calendars from the Medical Faculty. (McGill University, Faculty of Medicine Annual Calendar: Sixty-Ninth Session, 1901-1902 (Montreal: Gazette Printing Co. 1901), Osler Library of the History of Medicine, McGill University)

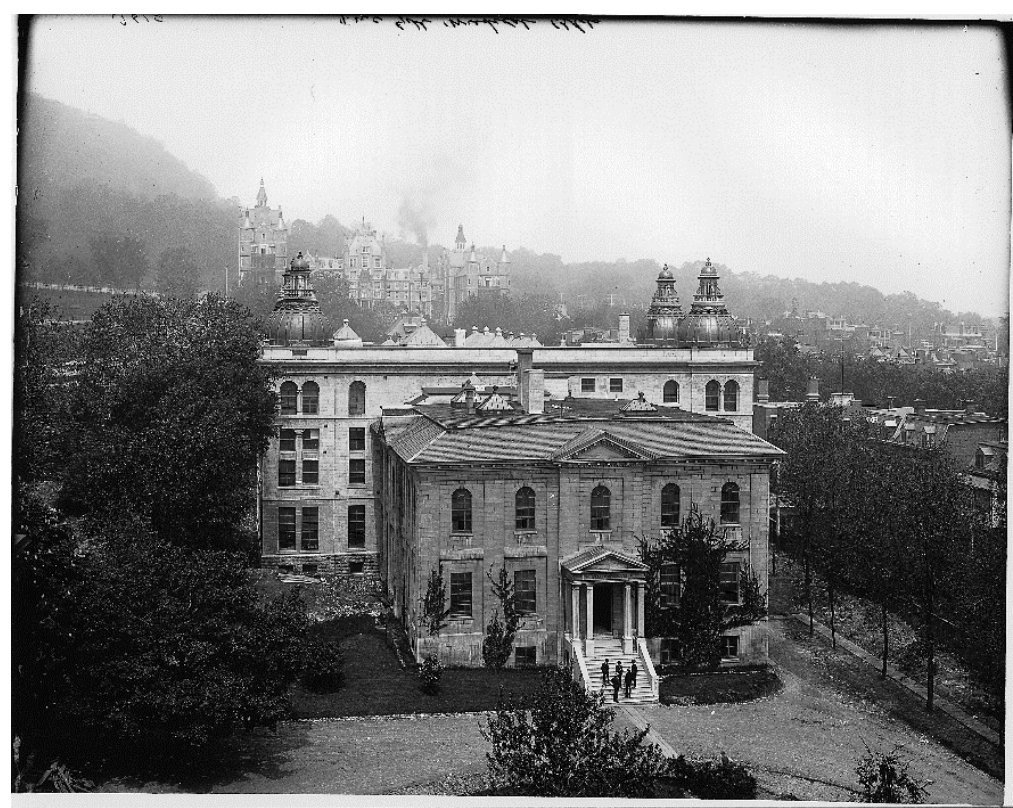

Figure 4. Photograph of Old Medical, McGill University, Montreal, about 1900. (VIEW-3619, McCord Museum, Montreal)

building (Figure 5) was the outcome of an architectural competition, eventually won by Brown \& Vallance. Seven other architecture firms were invited to participate in the competition, submitting plans, elevations, and sections for the new building on the busy corner of Pine Avenue and University Street, the northwest corner of the campus. The competition identified no cost limitations, and aside from a list of programmatic elements, included no other special requirements. The submissions were remarkably diverse, representing the architects' own interpretations of the complex site and program adjacencies necessary for medical education. As such, they are outstanding architectural evidence for understanding (and encountering) the history of medical education. ${ }^{19}$

Brown \& Vallance's winning scheme gave the museum utmost importance, with adjacent spaces defined only through their relationship to the gallery spaces. The architectural evidence thus confirms the importance of

19 There is only one study of the architectural history of medical education (Carroll, 2012). The Faculty of Medicine occupied the Strathcona Medical Building until 1965. 


\section{Otis Elevators}

\section{Electric and Hydraulic}

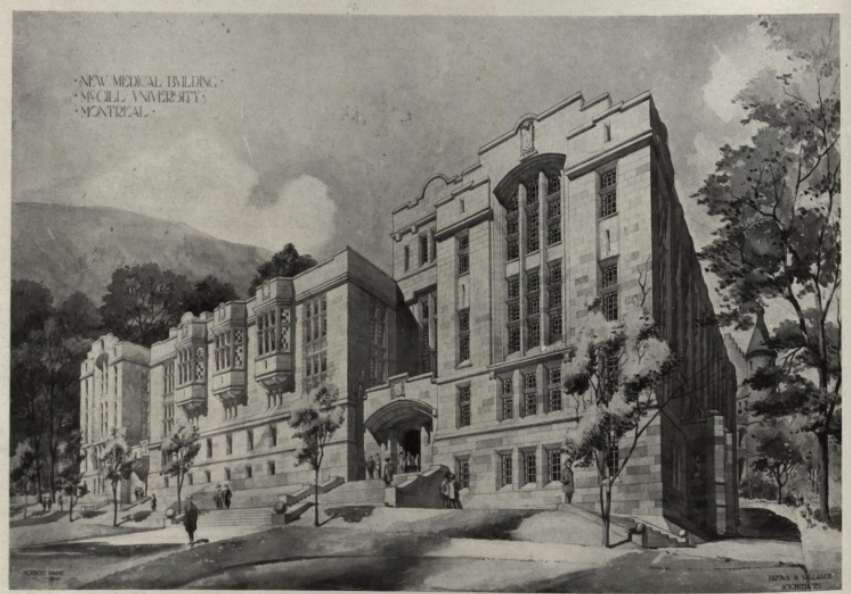

MoGill College Buildings, Equipped with Otis Elevators

Manufactured and Installed in Canada by

Otis-Fensom Elevator Co., Limited

Head Office-TORONTO, ONT.

Works-HAMILTON, ONT.

Figure 5. Otis Elevators advertisement featuring the Strathcona Medical Building, McGill University, Montreal. (Construction 5(4) (March 1912), 36)

Abbott's work in the context of the Faculty of Medicine and the university in general. The domed museum space also functioned as somewhat of a hinge between the Royal Victoria Hospital and the plan of McGill, with Abbott at its centre. A journalist writing in Canadian Architect \& Builder emphasised the connections of the museum with other spaces:

In the centre is the museum, top-lighted, and having two galleries. On each floor the outer corridors of this museum form the communication with the pieces in front and rear of the centre block [...] In this way good corridors of communication all around the museum are secured on each floor. The main stairways of the building being in direct proximity to the museum, the museum itself is not cumbered by special stairs of its own. [...] In the rear of the centre block is the principal assembly hall, with its platform against the rear wall of the museum (McGill Medical Building Competition, 1907).

Abbott's administrative centre was likely in a 43 x 30 foot, tripartite room on the ground floor (Figure 6) just east of the museum. Functioning as a workroom, prep room and museum storage, Abbott likely shared these quarters with the specimens yet to be classified and prepared for display in her museum. According to the building's strict symmetry, this room has the identical footprint and location to the lecture room on the first floor and the anatomical theatre on the second floor, serving as evidence of how museum curatorship and teaching had equal value in the medical curriculum at this time. ${ }^{20}$ This type of evidence, in this case the siting of the building, the

${ }^{20}$ The plans were published in Turner (1912).

(C) 2018 by Author/s 


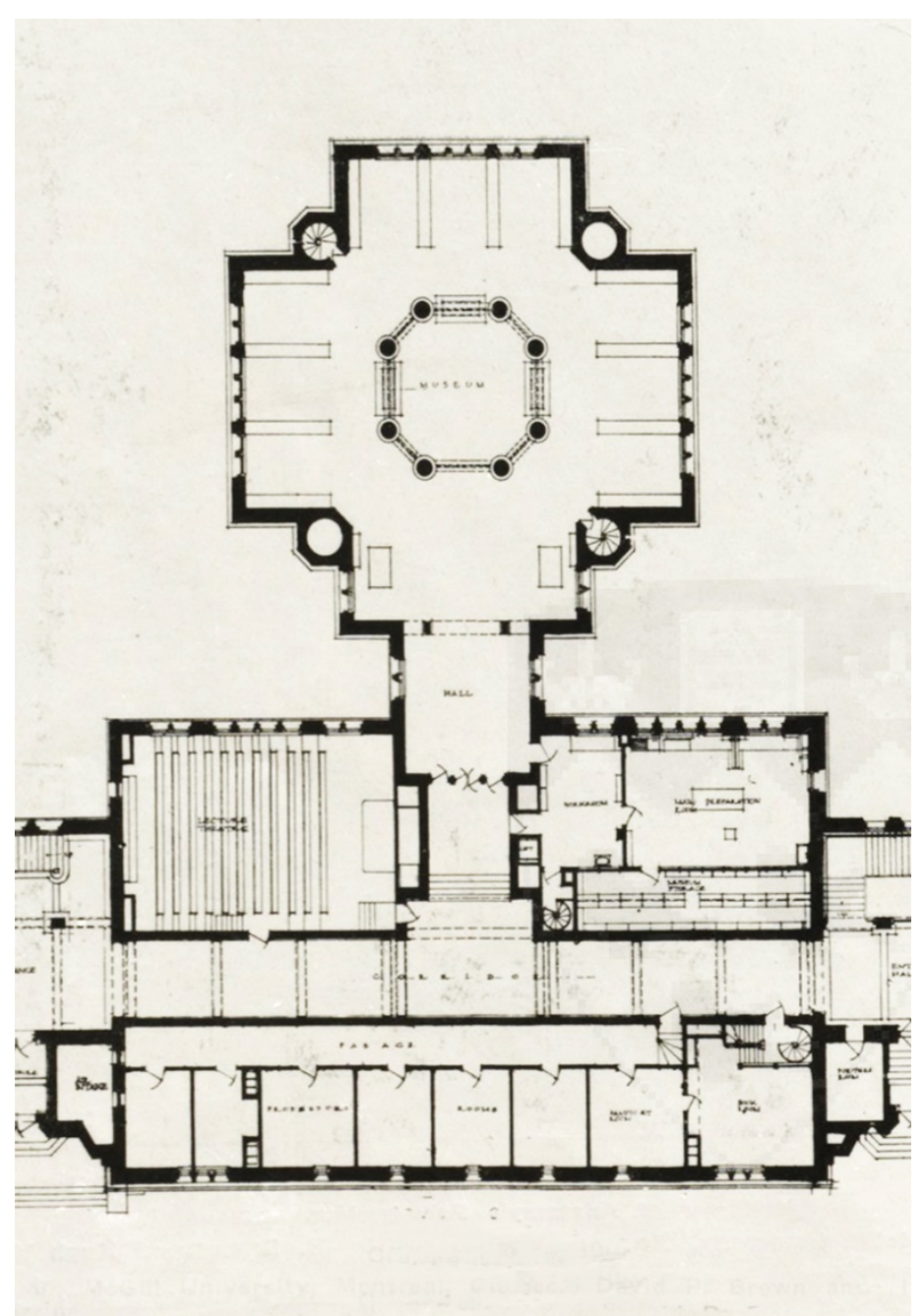

Figure 6. Partial view of the ground floor plan of the Strathcona Medical Building showing the museum's administrative centre, McGill University, Montreal. (Construction 5(4) (March 1912), 54)

location of the museum, and the footprint of her office, is never used by biographers. It points to Abbott's significant role in medical education at this time.

The campus site plan, too, Figure 7 shows how the museum and its larger container, the Strathcona Medical Building, occupy the 'heart' of medical education and serve as a connector between the hospital and the university. This relationship is articulated clearly by the axial layout of the plan which lines up with the main entrance of the Royal Victoria Hospital, its immediate neighbour to the north, while at the same time providing gracious entries to the campus on the south. As the specimen collection moved into the new Strathcona Medical Building, Abbott oversaw the transfer of surviving material and was given a blank slate upon which to realise her ideal museum. She thus operated as an 'actor' in the museum, in the sense intended by Susan Mann Trofimenkoff in her feminist critique of biography: "When so much of our cultural heritage has stressed women's passivity, feminist biography allows us to see women as actors" (1985: 4). Abbott adapted the new space, 'bringing her intense work habits to bear' (Brookes, 2011: 182). She had a revered capacity for work and gave a 'meticulous and detailed order' to the museum, creating a world-renowned, invaluable resource to medical students and researchers (Brookes, 2011: 172). Under her watch, the museum 'functioned as a mechanism for honing the eye, practicing the skills of observation, and learning how to see' (McLeary, 2001: 23).

By seeing museums as 'distributed institutions,' historian Kate Hill has convincingly argued that 'women made museums modern, while museums made women modern' (2016: 220). In her 2016 study, Women and Museums, 1850-1914, she shows how museums in Britain during Abbott's era blurred the boundaries between public and private, or the scholarly and the domestic, opening up the institution to a much wider public. Hill says,

A feminine vision of modern culture did not distinguish between or ascribe differential values to knowledge and affect, research and engagement, old and new, seeing them all as ways of negotiating a new, modern world (2016: 2). 


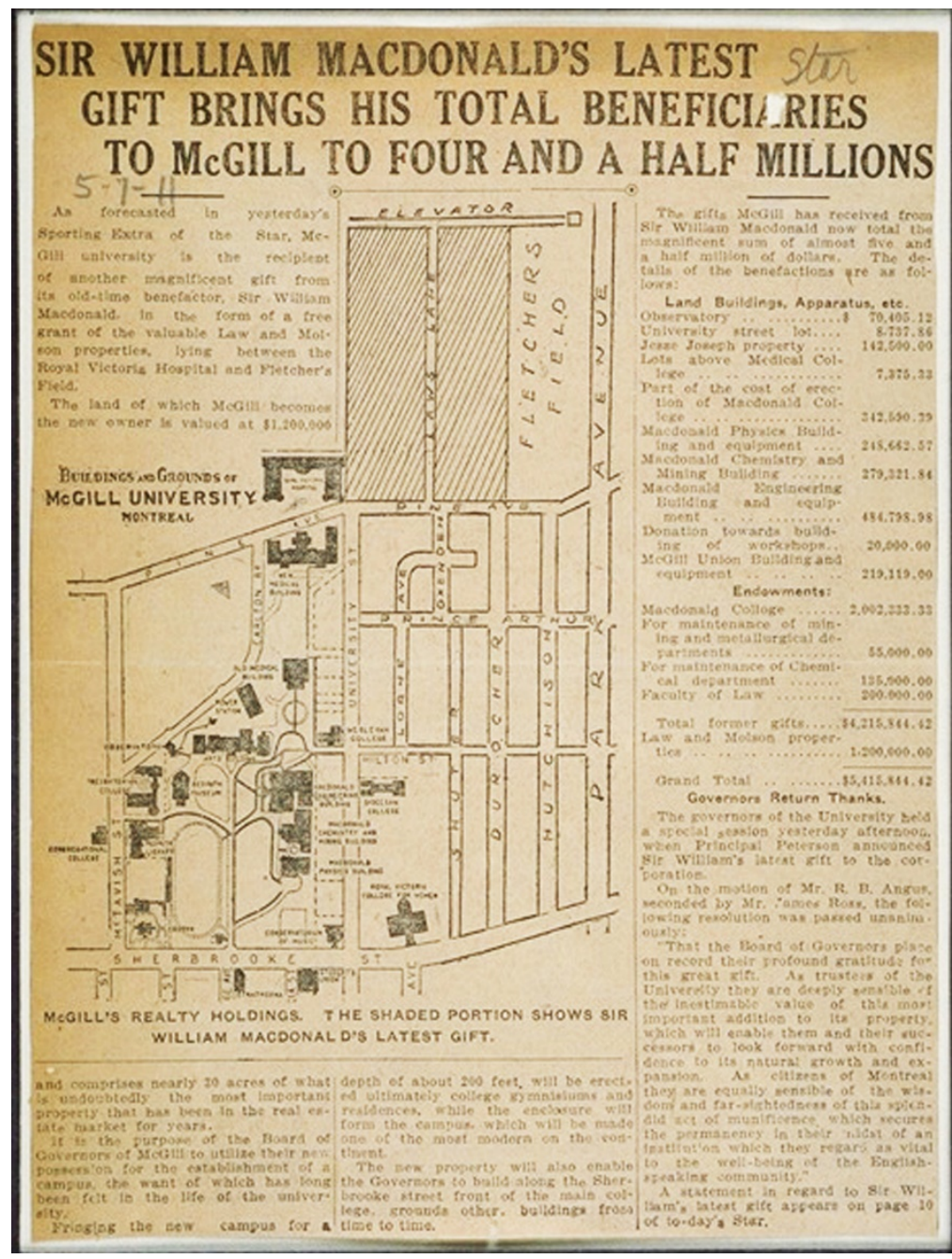

Figure 7. Newspaper article including plan of the McGill University campus. (Montreal Star, 1911)

Did Abbott's penchant for collecting and arrangement serve to 'domesticate' the hospital? Did her work at the medical museum (in addition or perhaps even more than Osler) thus facilitate the acceptance of her clinical research? Hill's work shows, too, how museums granted women agency while at the same time, contained it, which is precisely the role of the medical museum in Abbott's list of accomplishments (2016: 6).

Among the most interesting of Abbott's visual legacies is her depiction in painter Diego Rivera's $A$ History of Cardiology murals for the National Institute of Cardiology in Mexico City (see Lomas, 2005). Cardiologist Ignacio Chávez commissioned the two murals in 1944 at the time he founded the institute (Chávez, 1946). Like the photographer of the RVH surgical theatre, Rivera positions Abbott at the top of a pyramidal composition. The notes Chávez gave to Rivera asked that the murals

should indicate the ascending trend of knowledge and if possible should express how slow and difficult has been the advance, how each of those men had to fight routine, prejudice, ignorance and fanaticism [...] If you could find the way, it would be beautiful to paint this group of men moving, striving in an upward march (quoted in Lomas 2005: 1534).

The only Canadian included, Rivera's Abbott tends to a child and is accompanied by a uniformed nurse (assuring she is not read as a nurse herself). Perhaps conscious of the significance of material culture in Abbott's career, Rivera also included a museum specimen and a drawing from her celebrated atlas (Figure 8). Nonetheless and perhaps because she appears to be tending to a child, some art historians have emphasised her work as a paediatric cardiologist (Lomas, 2007: 472). I would assert that Rivera was also including a reference to Abbott's mobility, looking to a photograph (Figure 9) from California included in MacDermot's biography: a snapshot from her post-retirement lecture tour (1936+) in California (1941: 186-7).

A spatial, material culture approach leads us to another important artefact, the so-called Holmes heart, which came from an autopsy of 1823. The unusual heart had three chambers and had been used by Osler as a demonstration specimen with students. According to MacDermot, the heart had been mislabelled 'ulcerative endocarditis,' while it actually had no ventricular septum (1941: 76). Osler had directed Abbott to Andrew Holmes' 


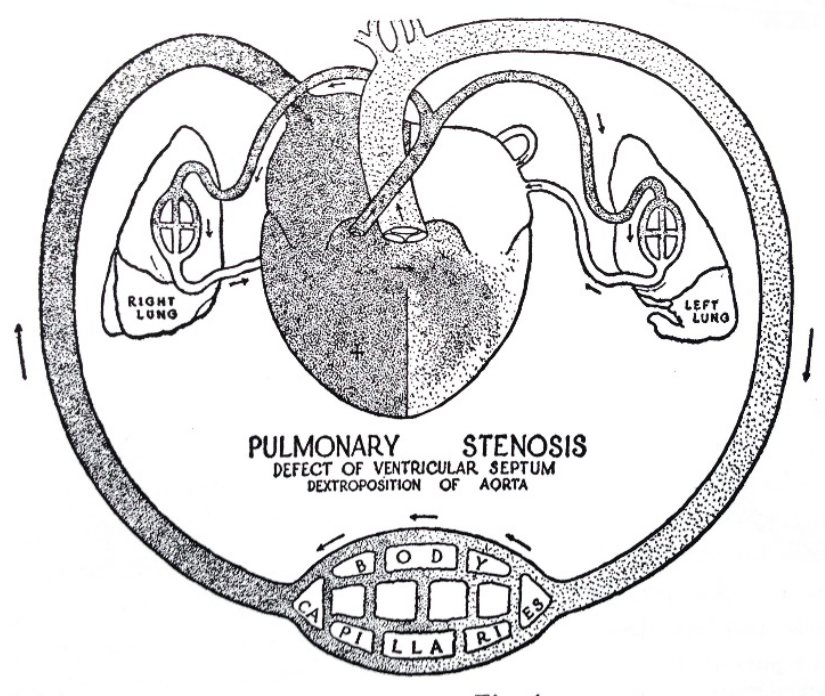

Fig. 1.

Figure 8. Maude E. Abbott, Pulmonary Stenosis and Atresia with Defect of Ventricular Septum (Tetralogy of Fallot), 1936. (Maude E. Abbott, with an introduction by Richard Fraser, Atlas of Congenital Cardiac Disease)

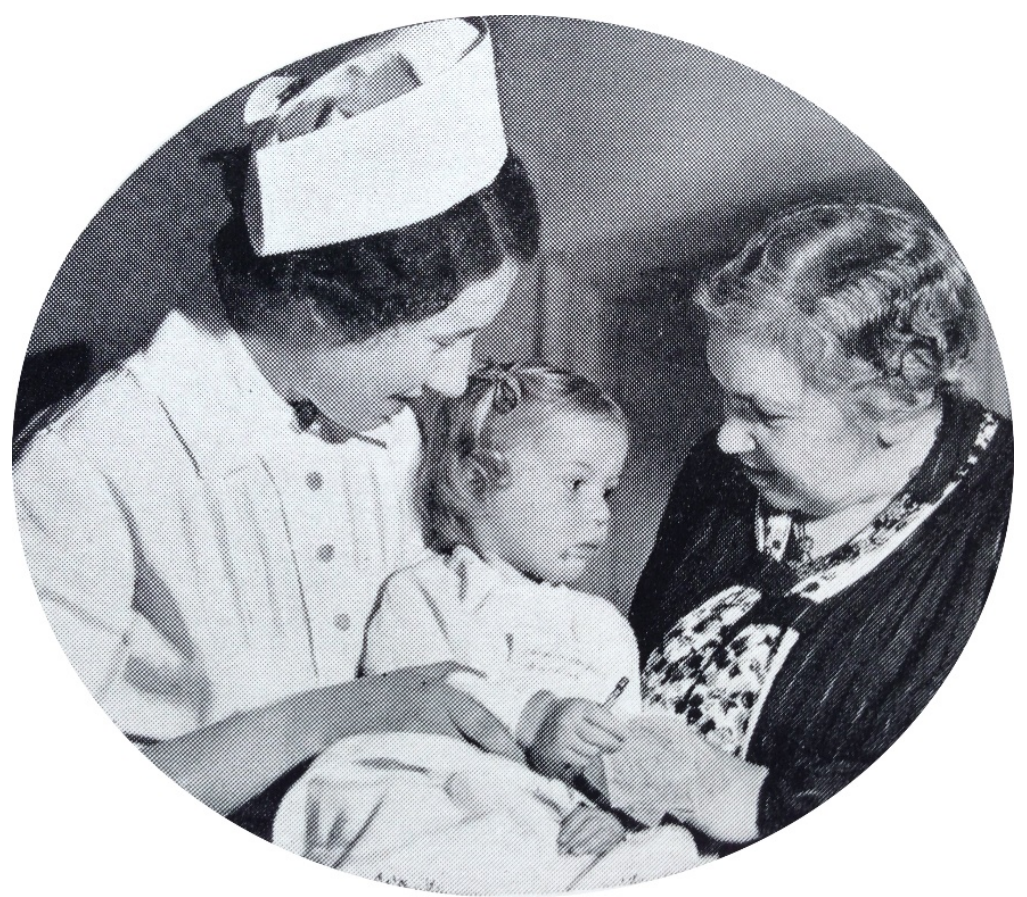

Figure 9. Photograph of Abbott during her post-retirement lecture tour in California. (H.E. MacDermot, Maude Abbott: A Memoir)

description of it in the Transactions of the Medico-Chirurgical Society of Edinburgh of 1824, which she republished in the Montreal Medical Journal in July 1901. Abbott herself 'traces her original interest in congenital heart disease to the finding' of the Holmes heart (MacDermot, 1941: 97). In this instance, then, Abbott's scientific work on the heart was only tangentially related to Osler. Nonetheless, Osler's input is unduly emphasised by her biographers.

Finally, Abbott's influence as a curator waned when the collection moved from the Strathcona Medical Building to the Pathology Institute (Figure 10) in 1923, designed by Scottish-born, Montreal-based architect and educator Percy Nobbs. According to biographers, Abbott's former technician, Ernest Lionel Judah, moved with the collection to the new Pathology Institute, while Abbott stayed in the Strathcona Medical Building as the curator of what came to be called the Central Medical Museum. Pathologist Horst Oertel, who articulated a clear idea of what the new pathology building was intended to serve and to mean, was notably unsupportive of Abbott, closing another door. By the 1930s, the rotunda in the Strathcona Medical Building, which had once housed Abbott's specimens, accommodated historic totem poles and spinning wheels. Indeed, medical historian Jonathan Reinarz 


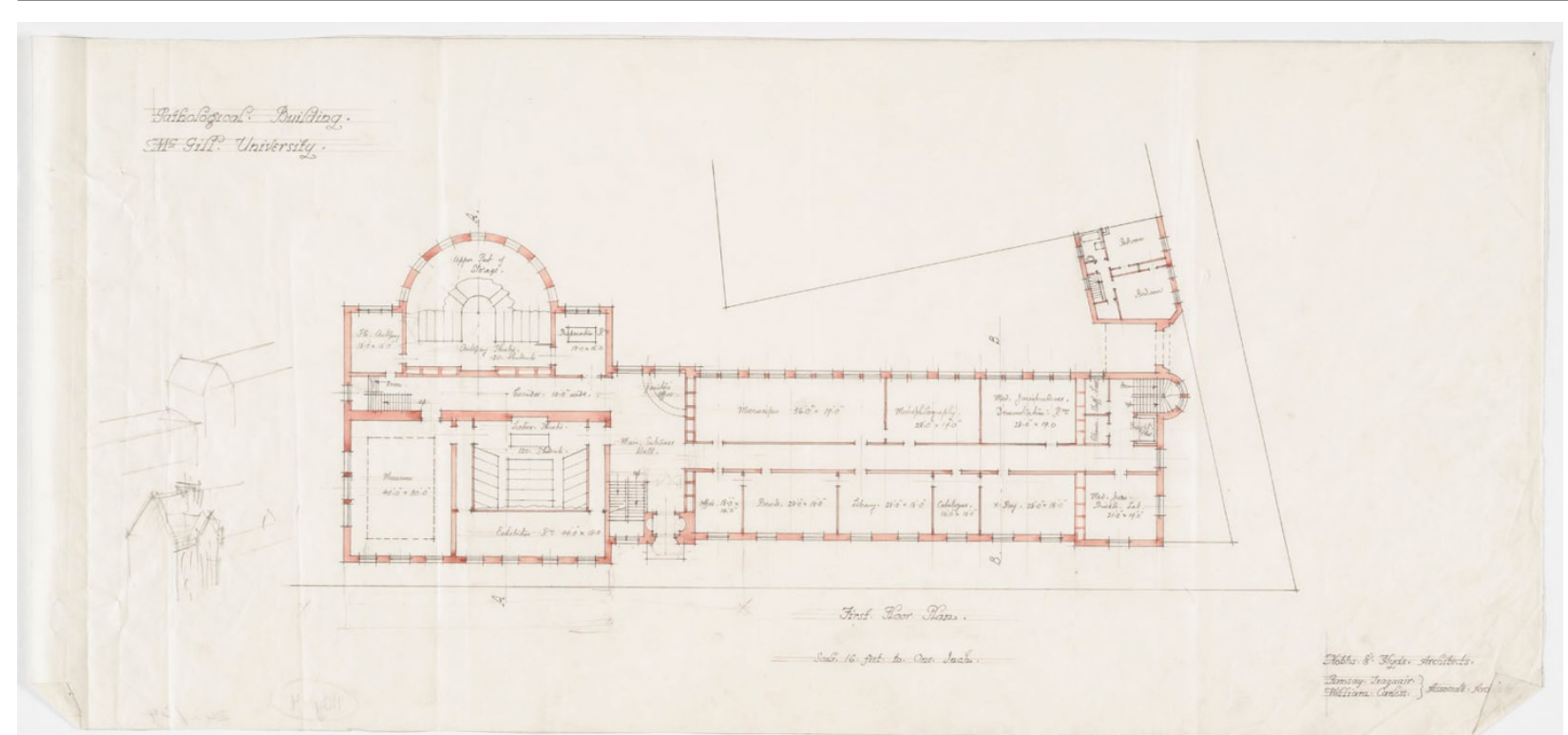

Figure 10. Nobbs \& Hyde, Architects, First Floor Plan of the Pathological Institute, McGill University, Montreal, ca. 1922-1924. (Courtesy of John Bland Canadian Architecture Collection, McGill University Library)

has noted that the importance of museums waned in general in medical education about World War II (2005: 435); this material evidence, however, suggests the decline began a generation earlier. ${ }^{21}$

\section{Networks}

While these architectural traces point to her curatorial effectiveness and the importance of the museum in medical education, Abbott's professional network also had enormous impact. We can document this impact by looking at her publications and correspondence. Apart from her most famous book, Atlas of Congenital Cardiac Disease, ${ }^{22}$ Abbott's main textual trace is the run of the Bulletin of the International Association of Medical Museums, for which she served as editor for 31 years. She used the bulletin, described in its inaugural issue as an 'organ' (Introductory statement, 1907: 2), as an arena from which, for example, to call for new specimens after the McGill fire, to showcase diverse ways of displaying medical specimens, and to discuss the ideal medical museum. The inaugural issue had an astonishing 44 participating institutions (List of Organizing Members of the International Association of Medical Museums 1907: 6-8).

Relationships and networks have been a central theme in feminist biography as an effective way to capture women's life experiences. Booth and Burton exclaim that:

It is indisputable that the notion of a life as enmeshed in, and as in a sense organizing, a network of circuits and connections is one that has been salient to feminist biographers as long as the practice of something that could be called feminist biography has been around (2009b: 8).

One of the problems with most of the existing biographies is how they do the opposite, spotlighting Abbott's isolation and difference, rather than her connections to others. I contend that two spatial networks show Abbott's rise to prominence in the medical world, completely invisible in the extant biographies: her correspondence and her contacts. This map (Figure 11) is a graphic analysis of the archive of Abbott's letters (numbering 213) currently held in the Maude Abbott Fonds, Osler Library of the History of Medicine, McGill University. The places of origin of correspondence received from named individuals appear here as red dots. The line from Montreal to Perugia, for example, is one piece of correspondence (in other words, the thickness of the black line shows the number of pieces). The city with the highest number of letters is New York. This map shows that during her career, Abbott's influence was far reaching, as many physicians wrote to her to gain advice on particular cases. Her reputation was global and her perspective was frequently sought.

A second map (Figure 12) shows the home bases of authors she brought to the bulletin from 1907 to 1938 . She saw the journal, I would argue, as a space for outreach, engaging it as a textual classroom or space that had global reach. Researchers and curators from around the world, especially the United States, presented their work in an orderly framework designed by Abbott. Her long-time role as Secretary of the International Association of

\footnotetext{
${ }^{21}$ On the museum's significance in imperial practices of classification and knowledge production during the Victorian era, see Barringer and Flynn (1998); Bennett (2004); Conklin (2013); Edwards et al. (2006); Hall (1997); Kriegel (2007); MacKenzie (2009).

22 The Atlas of 1936 is also a spatial trace as it was intended to be a published record of a series of exhibitions in 1931, 1932, 1935, and 1936 curated by Abbott that included specimens and graphic material. Fortunately for us this material is extant.
} 


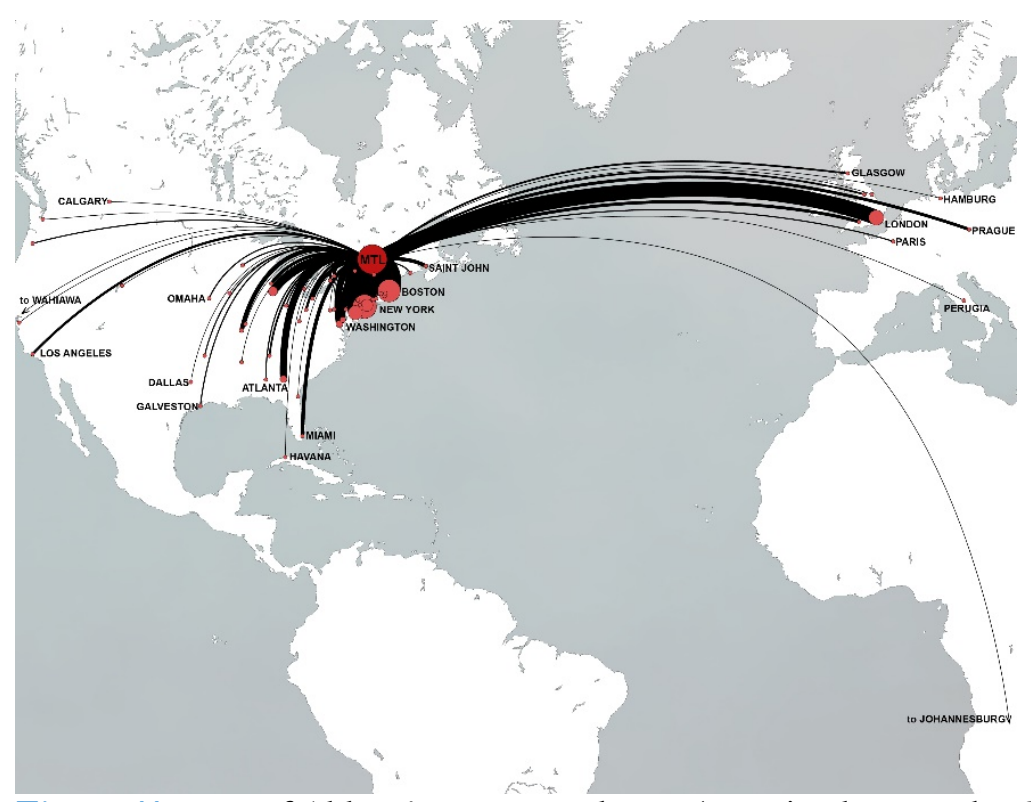

Figure 11. Map of Abbott's correspondence. (Drawing by Newsha Ghaeli, 2014)

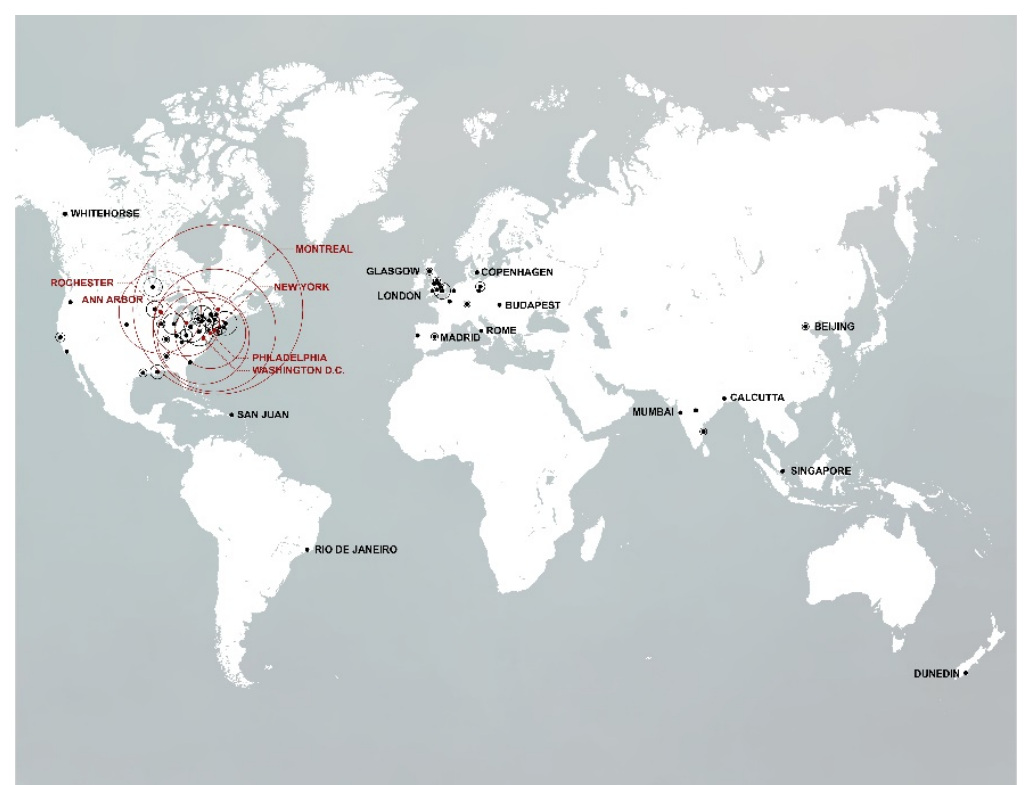

Figure 12. Map of the home bases of authors of the Bulletin of the International Association of Medical Museums, 190738. (Drawing by Newsha Ghaeli, 2014)

Medical Museums also helped to fund her travel and bring in funding. For example, in 1913 she attended a conference in London in this role. Her work resulted in a favourable mention in the Times, which she subsequently sent to Lord Strathcona, the benefactor of the Strathcona Medical Building. She requested 1,000 pounds and Lord Strathcona followed up with five times that amount. She was made 'permanent International Secretary,' travelling to Germany and Italy before returning home. Abbott's work as bulletin editor thus placed her at the hub of a vast network of institutions. Mapping Abbott's reach complements the other material and spatial evidence of her work and agency, linking the approach to the literature on feminist biography. And in practical terms, it also likely led to her appointment as Acting Editor of the Canadian Medical Association Journal during World War I (1959: 148-149), expanding her publishing network to another influential magazine.

\section{CONCLUSION}

'Encountering' Maude Abbott through material evidence offers a different understanding of her extraordinary work and life. Museum spaces in three unique buildings_-Old Medical, the Strathcona Medical Building, and the Pathology Institute- her correspondence and editorial work, portraits and photographs direct readers on a 


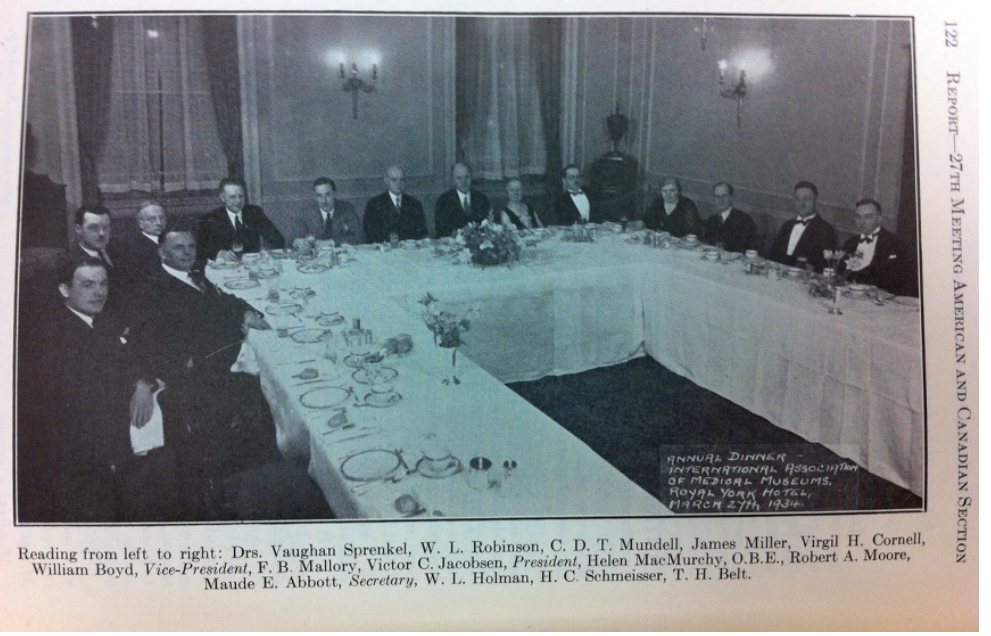

Figure 13. Photograph of the Annual Dinner, International Association of Medical Museums, Toronto, 27 March 1934, showing Maude Abbott in the top-right corner. (Report $-27^{\text {th }}$ Meeting American and Canadian Section, Osler Library of the History of Medicine, McGill University)

different course than the traditional signposts of the biographies we know: her rejection from McGill, curatorship over physician-ship, doors held variously open and closed by figures like Osler and Oertel.

What may not be obvious is that spatial approaches link architectural and art history and the medical humanities, enhancing all three disciplines. Engaging spatial and material evidence contributes additional sources and methods to those commonly used by scholars engaged in the medical humanities. In the case of Maude Abbott, a powerful new spatially and materially oriented reading intervenes in and brings into dialogue debates about feminist life writing and the medical humanities. For example, many medical humanities scholars focus on the patient experience, but Abbott's material and spatial traces show there is much more to uncover of physicians' experiences of early twentieth-century medicine, particularly for those like her in non-traditional roles and spaces. Employing architecture and art as primary sources, too, calls into question the dominance of narrative in the medical humanities. Anne Whitehead and Angela Woods, editors of The Edinburgh Companion to the Critical Medical Humanities, call for work that explores 'new scenes and sites' (2016: 2) that might 'offer alternative vantage points' (2016: 7), particularly those that '[open] up the question of the medical site' (2016: 22). Architectural history's focus on the hospital, for example, would miss the significant role of the medical museum altogether, embedded as it was in buildings designed for medical education in general. What of Abbott's significant activity with body parts and human specimens? This work is a misfit in a discipline that focuses on the history, sociology, and anthropology of patient care.

Let's return to where we began: Eastlake's portrait of An Old Woman. In revisiting the material evidence of Abbott's life story, I discovered (almost by accident) that it was likely painted from a photograph of the doctor taken at the International Association of Medical Museums annual dinner at the Royal York Hotel, Toronto, on 27 March 1934 (Figure 13). Did Eastlake use the photograph after the death of her friend? Was she perhaps making a subtle reference to Abbott's place and impact in this network? 'Encountering' the portrait with this photo in mind casts the representation in a different light, worlds away from the image of an anonymous old woman it was long thought to be. As we noted, Eastlake focuses on Abbott's confident and knowing look, removing all traces of deference and passivity. Via this abstraction, Eastlake also suggests that Abbott's impact was beyond medicine. The painting serves as more than a platform for viewing the subject, as Arnold asserts, but is rather a way to produce the subject (2008: 14). As such, it also shows how medical humanities research that engages alternative and especially material sources can destabilise traditional biography, making room for extraordinary women like Maude Abbott.

\section{ABOUT THE AUTHOR}

Annmarie Adams is Chair of the Department of Social Studies of Medicine and jointly appointed in the Peter Guo-hua Fu School of Architecture, McGill University, Montreal, Canada. 


\section{ACKNOWLEDGEMENTS}

An early version of this paper was presented at the $16^{\text {th }}$ Berkshire Conference on the History of Women in Toronto, 22-25 May 2014. I am grateful to Newsha Ghaeli for her assistance with this paper and especially for her skillful authorship of the maps of Abbott's spatial reach. Magdalena Miłosz provided a thorough review of the literature on feminist biography and assisted with final revisions. Also warm thanks to Richard Fraser and Joan O'Malley, Department of Pathology, for generously sharing Abbott's materials. Don Toromanoff, Chris Lyons and Jennifer Tu-Anh Phan also deserve many thanks. Catherine Desbarats, Peter Gossage, Mary Hunter, Peter McNally, Tristana Martin Rubio, Thomas Schlich, David Theodore, and two anonymous reviewers read versions and made helpful suggestions.

\section{REFERENCES}

Abbott, M. (1959). Autobiographical Sketch. McGill Medical Journal, 28(3), 127-152.

Abbott, M., with an introduction by Fraser, R. (2006). Atlas of Congenital Cardiac Disease. Montreal and Kingston, London, Ithaca: McGill-Queen's University Press.

Abbott, E. (1997). All Heart. Unpublished paper. Osler Library of the History of Medicine, McGill University.

Adams, A. (2017). Designing the Medical Museum, in S. Schrank and D. Ekici (eds.), Healing Spaces, Modern Architecture, and the Body (pp. 171-185). London: Routledge.

Alpern, S., Antler, J., Perry, E. I. and Scobie, I. W. (eds.) (1992). Introduction, in The Challenge of Feminist Biography: Writing the Lives of Modern American Women. Urbana, Ill.: University of Illinois Press.

Arnold, D. (2008). (Auto)biographies and space, in D. Arnold and J. Sofaer (eds.), Biographies and Space: Placing the Subject in Art and Architecture (pp. 6-16). London: Routledge.

Barringer, T. and Flynn, T. (eds.) (1998). Colonialism and the Object: Empire, Material Culture and the Museum. Abingdon; New York: Routledge.

Bennett, T. (2004). Pasts Beyond Memory: Evolution, Museums, Colonialism. Abingdon; New York: Routledge. https://doi.org/10.4324/9780203647066

Bliss, M. (1999). William Osler: A Life in Medicine. Toronto: University of Toronto Press.

Booth, M. and Burton, A. (2009a). Editors' Note: Critical Feminist Biography. Journal of Women's History, 21(3), 7 12. https://doi.org/10.1353/jowh.0.0093

Booth, M. and Burton, A. (2009b). Editors' Note: Critical Feminist Biography II. Journal of Women's History, 21(4), 8-12. https://doi.org/10.1353/jowh.0.0105

Brookes, B. (2011). An Illness in the Family: Dr. Maude Abbott and Her Sister, Alice Abbott. Canadian Bulletin of Medical History/Bulletin canadien d'histoire de la médecine, 28(1), 171-190. https:// doi.org/10.3138/cbmh.28.1.171

Byrne, P. (2013). The Real Jane Austen: A Life in Small Things. New York: Harper Collins.

Caine, B. (1994). Feminist Biography and Feminist History. Women's History Review, 3(2), 247-261. https:/ / doi.org/10.1080/09612029400200049

Carroll, K. (2012). Modernizing the American Medical School and its Architecture. PhD Thesis. Boston University.

Chávez, I. (1946). Diego Rivera: Sus Frescos en el Instituto Nacional de Cardiología. México: La Sociedad Mexicana de Cardiología.

Conklin, A. L. (2013). In the Museum of Man: Race, Anthropology, and Empire in France, 1850-1950. Ithaca: Cornell University Press.

Donoghue, E. (2009). A faint heartbeat, The Globe and Mail, 25 May.

Edwards, E., Gosden, C. and Phillips, R. (eds.) (2006). Sensible Objects: Colonialism, Museums and Material Culture. Oxford: Berg.

Fara, P. (2015). Women, Science and Suffrage in World War I. Notes and Records, 69(1), 11-24. https://doi.org/10.1098/rsnr.2014.0057

Frost, S. (1978). The Abbotts of McGill. McGill Journal of Education, 13(3), 253-270.

Gillett, M. (1989). The Lonely Heart: Maude E. Abbott, 1869-1940, in G. J. Clifford (ed.), Lone Voyagers: Academic Women in Coeducational Universities, 1870-1937 (pp. 183-222). New York: The Feminist Press.

Gillett, M. (1990). The Heart of the Matter, in M. Gosztonyi Ainley (ed.), Despite the Odds: Essays on Canadian Women and Science (pp. 179-194). Montreal: Véhicule Press.

Gordon, L. (2012). Dorothea Lange: A Life Beyond Limits. New York: Phaidon.

Hall, S. (ed.) (1997). Representation: Cultural Representations and Signifying Practices. London: Sage.

Heilbrun, C. G. (1988). Writing a Woman's Life. New York: Ballantyne.

Heilbrun, C. G. (1999). Woman's Autobiographical Writings: New Forms, in M. W. Brownley and A. B. Kimmich (eds.), Women and Autobiograpby (pp. 15-32). Lanham: Rowman and Littlefield. 
Hill, K. (2016). Women and Museums, 1850-1914: Modernity and the Gendering of Knowledge. Manchester: Manchester University Press.

Introductory statement. (1907). Bulletin of the International Association of Medical Museums, 1, 1-2.

Jordanova, L. J. (2000). Defining Features: Scientific and Medical Portraits 1660-2000. London: Reaktion and National Portrait Gallery.

Kriegel, L. (2007). Grand Designs: Labor, Empire, and the Museum in Victorian Culture. Durham and London: Duke University Press. https://doi.org/10.1215/9780822390534

List of Organizing Members of the International Association of Medical Museums. (1907). Bulletin of the International Association of Medical Museums, 1, 6-8.

Lomas, D. (2005). Painting the History of Cardiology. BMJ: British Medical Journal, 331(7531), 1533-1535. https://doi.org/10.1136/bmj.331.7531.1533

Lomas, D. (2007). Remedy or Poison? Diego Rivera, Medicine and Technology. Oxford Art Journal, 30(3), 454-483. https://doi.org/10.1093/oxartj/kcm022

MacDermot, H. E. (1941). Maude Abbott: A Memoir. Toronto: Macmillan.

McGill Medical Building Competition. (1907). The Canadian Architect and Builder, 20(8), 143-144.

MacKenzie, J. M. (2009). Museums and Empire: Natural History, Human Cultures and Colonial Identities. Manchester: Manchester University Press.

McGill University. (2018). Maude Abbott Medical Museum. Available at: http://www.mcgill.ca/medicalmuseum (Accessed 23 July 2018)

McLeary, E. (2001). Science in a Bottle: The Medical Museum in North America, 1860-1940. PhD Thesis. Philadelphia, PA: University of Pennsylvania.

Miller, M. (2010). Betsy Ross and the Making of America. New York: Henry Holt.

Osler, W. and McCrae, T. (1908). System of Medicine 4. London: Frowde.

Reinarz, J. (2005). The Rise and Fall of the Medical Museum at Birmingham's School of Medicine. Social History of Medicine, 18(3), 419-437. https://doi.org/10.1093/shm/hki050

Roland, C. (2003). Osler, Sir William, in Dictionary of Canadian Biography. Available at: http:/ /www.biographi.ca/en/bio/osler_william_14E.html (Accessed 12 July 2017)

Rothman, C. (2009). The Heart Specialist. Toronto: Cormorant.

Stanley, L. (1990). Moments of Writing: Is There a Feminist Auto/biography? Gender \& History, 2(1), 58-67. https:// doi.org/10.1111/j.1468-0424.1990.tb00079.x

Trofimenkoff, S. M. (1985). Feminist Biography. Atlantis, 10(2), 1-10.

Turner, P. J. (1912). The Medical Building, McGill University. Construction, 5(4), 47-57.

Ulrich, L. T. (2007). How Betsy Ross Became Famous. Common-place, 8(1). Available at: http://commonplace.org/vol-08/no-01/ulrich

Upton, D. (1996). Madaline: Love and Survival in Antebellum New Orleans. Athens, GA: University of Georgia Press.

Van Slyck, A. (1992). Women in Architecture and the Problems of Biography. Design Book Review, 25, 19-22.

Wagg, S. (2013). The Architecture of Andrew Thomas Taylor: Montreal's Square Mile and Beyond. Montreal: McGill-Queen's University Press.

Waugh, D. (1992). Maudie of McGill: Dr Maude Abbott and the Foundations of Heart Surgery. Toronto: Dundurn Press.

Whitehead, A. and Woods, A. (2016). Introduction, in A. Whitehead, A. Woods, S. Atkinson, J. Macnaughton, and J. Richards (eds.), The Edinburgh Companion to the Critical Medical Humanities. Edinburgh: Edinburgh University Press.

Wright, J., Fraser, R., Adams, A. and Hunter, M. (2017). Portraying Maude Abbott. Canadian Medical Association Journal, 189(7), 281-283. https://doi.org/10.1503/cmaj.160976

Citation: Adams, A. (2018). Encountering Maude Abbott. Feminist Encounters: A Journal of Critical Studies in Culture and Politics, 2(2), 21. https://doi.org/10.20897/femenc/3889

Copyright (C) 2018 by Author/s and Licensed by Lectito BV, Netherlands. This is an open access article distributed under the Creative Commons Attribution License which permits unrestricted use, distribution, and reproduction in any medium, provided the original work is properly cited. 